Vol. 51 , n. 3 : pp.569-579, May-June 2008 ISSN 1516-8913 Printed in Brazil
BRAZILIAN ARCHIVES OF BIOLOGY AND TECHNOLOGY

A N INTERNATIONAL JOURNAL

\title{
Intensity of Bitterness of Processed Yerba Mate Leaves Originated in two Contrasted Light Environments
}

\author{
Miroslava Rakocevic ${ }^{1 *}$, Moacir José Sales Medrado ${ }^{2}$, Fernando Lucambio ${ }^{3}$ and Alice Teresa \\ Valduga $^{4}$ \\ ${ }^{1}$ Embrapa Informática Agropecuária; Avenida André To 209; Barão Geraldo; mima@cnptia.embrapa.br; 13083-886; \\ Campinas - SP - Brazil. ${ }^{2}$ Embrapa Florestas; Estrada da Ribeira, km 111; medrado@cnpf.embrapa.br; 83411-000; \\ Colombo - PR - Brazil. ${ }^{3}$ Departamento de Estatística; Universidade Federal do Paraná; lucambio@ufpr.br; 81531-990; \\ Curitiba - PR - Brazil. ${ }^{4}$ Universidade Regional Integrada do Alto Uruguai e das Missões - URI; Avenida Sete de \\ Setembro 1621, alice@uri.com.br; 99700-000; Erechim - RS - Brazil
}

\begin{abstract}
The bitterness intensity of beverage prepared from the leaves produced on the males and females of yerba mate (Ilex paraguariensis), grown in the forest understory and monoculture, was evaluated. The leaves were grouped by their position (in the crown and on the branch tips) and by the leaf age. The leaf gas exchange, leaf temperature and photosynthetic photon flux density were observed. Inter and intra-specific competition for light and self-shading showed the same effect on yerba mate beverage taste. All the shading types resulted in bitterer taste of the processed yerba mate leaves compared to the leaves originated under the direct sun exposure. The leaves from the plants grown in the monoculture showed less bitterness than those grown in the forest understory. This conclusion was completely opposite to the conventionally accepted paradigm of the yerba mate industries. The leaves from the tips (younger leaves) of the plants grown in the monoculture resulted a beverage of softer taste; the males produced less bitter leaves in any light environment (forest understory or in the crown in monoculture). The taste was related to the photosynthetic and transpiration rate, and leaf temperature. Stronger bitterness of the leaves provided from the shade conditions was related to the decreased leaf temperature and transpiration in the diurnal scale.
\end{abstract}

Key words: Leaf age, photosynthesis, shade, stomatal conductance, temperature, transpiration

\section{INTRODUCTION}

Yerba mate (Ilex paraguariensis St. Hil., Aquifoliaceae) a diploid (Scherer, 1997), cryptic dioecious species, originated in the South of Brazil, Uruguay and Paraguay (Hoppe et al. 1996), is of great social-economic role (Mosele, 2002). In its natural habitat this evergreen tree occurs in the subcanopy of the subtropical rainforest with Araucaria angustifolia (Petersen et al., 2000) where it reaches $15 \mathrm{~m}$ height, whereas in the exploration process yerba mate plants are cut currently at each one, two or three years and are managed as shrubs up to 2.5-3.0 $\mathrm{m}$ height.

Industrially processed leaves and fine branches of yerba mate are used for the preparation of different types of the beverages: "chimarrão", green yerba mate tea, black yerba mate tea, toasted yerba mate tea, and different instantaneous forms of soluble tea, all with the tonic and stimulate properties due to the caffeine, theofiline, and theobromine (Ashihara, 1993; Saldaña et al., 2000; Esmelindro et al., 2005).

* Author for correspondence 
Recently, it was determined that yerba mate leaves, as well as the leaves of the tea plants, coffee or cacao grains, contained the chlorogenic acid and other components with peroxidase-like-activity (Anesini et al., 2006), playing an active role in different disorder diseases (Lunceford \& Gugliucci, 2005). The chemical composition of the raw material and the process of the preparation (Anesini et al., 2006) influence the taste of the final product and, in consequence, its acceptance in the market. The Brazilian market demands the "chimarrão" of normal to soft taste.

In modern the production systems, yerba mate is cultivated in the monoculture, with the cover crops (Piccolo et al., 2004), in the agroforestry systems (Eibl et al., 2000, Dedecek et al., 2003), or shaded in the forest understory. In order to increase the profitability, yerba mate cultivation in the monoculture increased in last fifteen years, especially the dense plantations. Generally, in the plant communities, each plant or organ is submitted to heterogeneous light environment created by shading from other organs in the same plant (selfshading effect) and neighbouring plants. Local climate modifications in the organ or plant level are important for the evaluation of the biological functions (Lemaire, 1995). Light is often a limiting factor considering inter- and intra- specific competition between the plants and plant organs. The photosynthesis, stomatal conductance, Rubisco activity (Heraut-Bron et al., 1999), and leaf carbohydrates are quickly affected by the irradiance reduction (Correia et al., 2006). Shade inducedlimitation in the sugar accumulation is expected to alleviate the end-product inhibition of the photosynthesis (Paul \& Foyer, 2001).

Recently, some biological functions of yerba mate were described. It shows annual growth periodicity, with two growth pauses, and two flushes of the regrowth (Bazzo \& Rakocevic, 2005). Moreover, the seasonality in the gas exchange was observed, which accompanied the growth flushes and pauses (Rakocevic et al., 2005). Sex physiological dimorphism in the gas exchange rates has been shown in Ilex paraguariensis, where the female plants were superior to the males (Rakocevic et al., 2007a). The first trial correlating the sensorial properties with the plant sex resulted in less bitter beverage prepared from the leaves originated from the male compared to the female plants, especially when prepared from the leaves originated from the tree tips (Rakocevic et al., 2007b).
The paradigm of yerba mate industries (with no scientific confirmation) is that the normal to soft taste of "chimarrão", originates from the plants grown in the forest or agroforestry systems, and the leaves and fine branches have to be collected in a minimum two-years intervals. Thus, the hypothesis that the shading promotes the physiological and sensorial modifications on yerba mate leaves was originated. Therefore, the objectives of the present study were to determine: 1/ what type of the shading influences the taste modification, the cultivation in the forest understory or the self-shading given by different positions of the leaves on the tree crown; 2/ if the leaf age, and, $3 /$ the plant sex influence the taste; 4/ how the taste is determined by the microambient factors and gas exchange properties in a function of the light resource distribution.

\section{MATERIAL AND METHODS}

\section{Study site}

The trial was conduced in the field at "Barão" yerba mate industry, Barão de Cotegipe ( $27^{\circ} 37^{\prime} 15^{\prime}$ ' S, $52^{\circ} 22^{\prime} 47^{\prime}$ ' W, $765 \mathrm{~m}$ average elevation), State of Rio Grande do Sul, Southern Brazil. The climate is defined as the subtropical humid (Cfa) by Köppen classification, with the precipitations regularly distributed during the year, and average temperature higher than $22^{\circ} \mathrm{C}$ in the hottest month. The soil was classified as the Rhodic Haplodux.

Two areas were chosen; one in the disturbed forest enriched with yerba mate plants (forest understory), and other in yerba mate monoculture. They were localized $100 \mathrm{~m}$ apart.

\section{Plant description}

Yerba mate plants for the two systems of the cultivation originated from the same seed collection. The seeds were collected in the summer 1998. The seedlings were planted in the monoculture $(2.5 \times 1.5$ $\mathrm{m})$ and the forest understory $(2.5 \times 2.5 \mathrm{~m})$ in the spring 1999. The pruning of the formation was carried out in 2001. Fifteen yerba mate plants were identified in each light environment (monoculture and forest understory) and the pruning was conduced in April 2003. Three buds were marked on each of the 30 identified plants and their growth was observed during two years. New leaf emission was observed frequently (15-30 days). The leaves were grouped in two-month-populations and in the beginning of each two-month-interval were 
identified by the plastic thickets. The sex of the plants was determined in the flowering stage.

\section{Leaf gas exchange and microclimate measurements}

The photosynthetic photon flux density (PPFD $\mu \mathrm{mol}$ photons $\left.\mathrm{m}^{-2} \mathrm{~s}^{-1}\right)$, leaf and air temperatures $(T l$ and $\left.\mathrm{Ta}-{ }^{\circ} \mathrm{C}\right)$, net photosynthesis $\left(A-\mu \mathrm{mol} \mathrm{CO} \mathrm{C}^{-}\right.$ $\left.{ }^{2} \mathrm{~s}^{-1}\right)$, stomatal conductance $\left(g_{s}-\mathrm{mol} \mathrm{m} \mathrm{m}^{-2} \mathrm{~s}^{-1}\right)$, and transpiration $\left(E-\mathrm{mol} \mathrm{H}_{2} \mathrm{O} \mathrm{m} \mathrm{m}^{-2} \cdot \mathrm{s}^{-1}\right)$ were measured with LI-6200 analyzer (LICOR, Nebraska, USA). The measurements were carried out during the period of the highest diurnal assimilation (10:0014:30) in May 2005, twenty-five months after the previous pruning (simulation of optimal pruning).

The measurements were conduced on the leaves of known age marked in two-month-intervals. Depending on the periodicity of the leaf emission, the growth pauses and leaf shedding, not all the leaf populations were present. Moreover, not all the observed leaf populations were present on each measured branch. In the forest shade lower leaf emission and shedding on yerba mate plants were observed, resulting in the presence of the leaf populations of $1,3,7,13,15,17,19$ and 21 months, whereas in the monoculture leaf populations of 1,3,7 and 17 months (other leaf populations shed) were observed. For this reason, in our study were measured more than 400 leaves.

\section{Light microclimate description}

The light environment in the two cultivation systems was assessed during two-years-period at two heights $(2.0 \mathrm{~m}$ and $1.2 \mathrm{~m})$. The radiation was evaluated on a basis of sequential measurements obtained by LI190AS radiation sensor, (measure photosynthetically active radiation - PPFD on the $400-700 \mathrm{~nm}$ wavebands in $\mu \mathrm{mol} \mathrm{m} \mathrm{m}^{-2} \mathrm{~s}^{-1}$. The values were registered as averages calculated for the periods of 10 minutes.

The photosynthetic photon flux density (PPFD) reaching those heights was compared to an open area. Only $2-10 \%$ of PPFD reached the yerba mate leaves under the forest shade compared to the open area, with no evident difference between the two heights simulating inside and tip position of yerba mate crown. In yerba mate monoculture, the PPFD that attained the leaves of tips $(2.0 \mathrm{~m})$ and inside the crown $(1.2 \mathrm{~m})$ were $62-90 \%$ and $31-71 \%$ of the PPFD in the open area, respectively. Moreover, the leaf temperature (measured by LI-6200) in the shade was modified. During the diurnal-day period in the autumn-winter, yerba mate leaf temperature was 5 to $9^{\circ} \mathrm{C}$ lower in shade of forest understory compared to the leaves in the sun from monoculture.

\section{Sensorial analysis}

The leaves and thin branches were separated and grouped by the position and defined by the leaf age populations to evaluate the bitter intensity. The leaf collection procedure differed for the monoculture and forest understory, because of different leaf emission rhythmicity. For both the light environments (monoculture and forest understory) two crown positions were considered: inside the tree (IN) and branch tips (PO). The plants in the monoculture contained one- and three-months-old leaf populations on the branch tips, whereas sevenand seventeen-months-old leaf populations inside the trees. Yerba mate plants from the forest understory contained one-, tree- and seven-monthsold leaf populations on the branch tips and inside of trees populations of 13-15-17-19 and 21 months.

The soluble extracts of the processed yerba mate were prepared by the water percolation in a fixed site with the crushed material (Valduga et al., 2003). The sensorial hedonic test of the soluble yerba mate extracts was conduced in the Laboratory of Sensorial Analysis of URI, Erechim, in the cabins containing blue, green and red light. The group of seven semi-trained testers judged the bitter taste in a qualitative scale from 1 to 10 (Amarine et al., 1965; Lamond, 1977) during the afternoon-day-period from 15:00 to 17:00. The infusions on $50-60^{\circ} \mathrm{C}$ were offered to the testers in a volume of $100 \mathrm{ml}$ in the PVC disposable cups. The hedonic test characterized the soft (1-4), normal (5-7), and bitter taste (8-10).

\section{Statistical methods}

The ordered categorical data frequently arise in the biological, biomedical and other research areas. Sometimes, the categories are the result of the grouping continuous data, such as the age, or they arise when the measurement was inherently imprecise. However, the ordinal data often resulted from the subjective assessments under ordered categories. The regression models for the ordinate data are applied to relate an ordered categorical dependent variable to a set of discrete and/or continuous covariates, restricting our considerations to the models describing the order of categories by using an order of the dependent variable subject to the effect of covariates.

The proportional odds model is considered a special case of the grouped continuous approach 
(McCullagh, 1980). It considers $\mathrm{Y}$ as a dependent variable with the ordinal categorical outcomes denotes by $1, \ldots \mathrm{G}$ corresponding to their order, and $\mathrm{x}$ $=\left(\mathrm{x}_{1}, \ldots, \mathrm{x}_{\mathrm{p}}\right)$ as $\mathrm{p}$-dimensional vector of covariates. The proportional odds model is given by:

$$
\begin{gathered}
\operatorname{Pr}(\mathrm{Y} \leq \mathrm{s} ; \mathrm{x}) / \operatorname{Pr}(\mathrm{Y}>\mathrm{s} ; \mathrm{x})=\exp \left(\theta_{\mathrm{s}}-\mathrm{x} \beta\right) \\
\mathrm{s}=1, \ldots, \mathrm{G},
\end{gathered}
$$

or equivalently for equation (2):

$$
\operatorname{Pr}(Y \leq s ; x)=\exp \left(\theta_{s}-x \beta\right) /\left\{1+\exp \left(\theta_{s}-x \beta\right)\right\}
$$

with the unknown parameters $\theta_{1}, \ldots, \theta_{\mathrm{G}}$. Here $\operatorname{Pr}(\mathrm{Y} \leq$ $\mathrm{s}$; $\mathrm{x})$ denotes the probability of the event $(\mathrm{Y} \leq \mathrm{s})$ for given $x$ and $\beta=\left(\beta_{1}, \ldots \beta_{\mathrm{p}}\right)^{\mathrm{T}}$ is a column vector of the unknown regression coefficients. The applications of this model were discussed under various aspects (Ashby et al., 1986; Cox \& Chuang, 1984).

In the current experiment the note of the bitter taste was considered as the ordered response factor in the sensorial analysis, where $G=10$. The light environment, leaf position and sex were considered as the discrete covariates, while $A, g_{s}, E, T l$, PPFD and age were considered as the continuous covariates.

\section{RESULTS}

Table 1 shows the results of the maximum likelihood estimation in the proportional odds model, where $\operatorname{Pr}(>|t|)$ meant the P-value. In the ordered categorical response variable regression, the light environment (forest or monoculture), leaf position, $A, E$ and $T l$ showed the significant effect on the intensity of the bitter taste and were considered as the significant variables, including the interaction light environment $x$ leaf position (Table 1). The net photosynthetic rate $(A)$ and leaf temperature $(T l)$ were considered as the significant continuous covariates, even if showed the relatively low significance level $(\mathrm{P}<0.1)$. The stomatal conductance $\left(g_{s}\right)$, photosynthetic photon flux density (PPFD), air temperature and leaf age did not show significant effect on bitter taste.

Table 1 - Regression model for bitter taste and ordered categorical response variables, general view. Significant codes: $\mathrm{P}<0.001^{\prime} * * *{ }^{\prime}, \mathrm{P}<0.01^{\prime} * *$ ', $\mathrm{P}<0.05^{\prime} *$ ' and $\mathrm{P}<0.1^{\prime} \bullet$ '.

\begin{tabular}{lccc}
\hline Variable & Coefficient & \multicolumn{2}{c}{ Pr $(>|\mathbf{t}|)$} \\
\hline Light environment & 0.7624 & $6.14 \times 10^{-5}$ & $* * *$ \\
Leaf position & 0.8352 & $2.04 \times 10^{-6}$ & $* * *$ \\
$g_{s}$ & -0.5412 & $1.17 \times 10^{-1}$ & \\
$A$ & 0.0495 & $5.01 \times 10^{-2}$ & $\bullet$ \\
$E$ & -78.003 & 0 & $* * *$ \\
PPFD & 0.0002 & $2.26 \times 10^{-1}$ & \\
$T a$ & 0.0766 & $2.91 \times 10^{-1}$ & \\
$T l$ & -0.124 & $8.98 \times 10^{-2}$ & $\bullet$ \\
Leaf age & 0.0109 & $4.58 \times 10^{-1}$ & \\
Sex & -0.7463 & $9.05 \times 10^{-16}$ & $* * *$ \\
\hline Light environment x Leaf position & -0.766 & $3.29 \times 10^{-4}$ & $* * *$ \\
\hline
\end{tabular}

After the fitting of the proportional odds model with the significant covariates, the final model was obtained demonstrating only the significant ordered categorical response variables influencing the bitter taste (Table 2). The response of bitter intensity was very complex and many factors were demonstrated to be important in the taste manifestation (note of bitterness). It was observed that there was no distinction between note 6 and note 7 (Table 3).

To distinguish visually the impact of different factors influencing the bitter taste note, the graphic representation was performed on the final model of the regression (Tables 2 and 3). Fig. are related to different situations concerning the discrete covariates (sex, light environment and leaf positions), demonstrating the variation of bitter taste depending on one of the significant ecophysiological factors $(E, A$ or $T l)$. The other two factors were fixed on their average values.

The graphic representation of all the shading situations (inter-specific and self-shading) showed similar responses for all the statistically significant continuous covariates separated by the effects of the sex and leaf position. In the females (Fig. 1) 
similar responses were demonstrated for the forest light environment (Fig. 1A and 1B) in all the leaf positions (leaves localized inside of crown and on branch tips), and surprisingly in the monoculture, inside of tree crown (Fig. 1C). The leaves originated from any type of the shaded environment showed bitterer taste than leaves from the branch tips in the monoculture (Fig. 1D). They were younger, appeared in the last year of regrowth, and considered the leaves under the direct sun exposure.

Table 2 - Final regression model for ordered categorical response variables influencing the intensity of bitter taste, after elimination of non-significant variables. In parenthesis is represented the situation where the intensity of bitter taste was significantly higher. Significant codes: $\mathrm{P}<0.001^{\prime} * * *$ ', $\mathrm{P}<0.01^{\prime} * *$ ', $\mathrm{P}<0.05$ '*' and $\mathrm{P}<0.1$ ' $\bullet$ '.

\begin{tabular}{lccc}
\hline Variable & Coefficient & Pr $(>|\mathbf{t}|)$ \\
\hline Light en. (SHADE) & 0.6410 & $1.16 \times 10^{-4}$ & $* * *$ \\
Leaf position (IN) & 0.8426 & $3.29 \times 10^{-8}$ & $* * *$ \\
$A$ & 0.0455 & $1.5 \times 10^{-2}$ & $*$ \\
$E$ & -85.9392 & 0 & $* * *$ \\
$T l$ & -0.049 & $1.51 \times 10^{-6}$ & $* * *$ \\
Sex (FEMALE) & -0.7558 & $1.83 \times 10^{-16}$ & $* * *$ \\
\hline Light en. (SHADE) x Leaf position (IN) & -0.6376 & $2.72 \times 10^{-4}$ & $* * *$ \\
\hline
\end{tabular}

Table 3 - Intercepts for notes 1-10. Significant codes: $\mathrm{P}<0.001^{\prime} * * * ', \mathrm{P}<0.01^{\prime} * *$ ', $\mathrm{P}<0.05^{\prime} *{ }^{\prime}$ and $\mathrm{P}<0.1$ ' $\bullet$ '.

\begin{tabular}{|c|c|c|c|c|}
\hline \multicolumn{2}{|c|}{ Notes } & \multirow{2}{*}{$\begin{array}{r}\text { Coefficient } \\
-3.6971264 \\
\end{array}$} & \multicolumn{2}{|c|}{$\operatorname{Pr}(>|\mathbf{t}|)$} \\
\hline 1 & 2 & & $5.41 \times 10^{-51}$ & $* * *$ \\
\hline 2 & 3 & -2.9673322 & $6.7 \times 10^{-37}$ & $* * *$ \\
\hline 3 & 4 & -2.4822963 & $2.49 \times 10^{-27}$ & $* * *$ \\
\hline 4 & 5 & -1.7233863 & $1.77 \times 10^{-14}$ & $* * *$ \\
\hline 5 & 6 & -0.7790024 & $4.31 \times 10^{-4}$ & $* * *$ \\
\hline 6 & 7 & 0.0733233 & $7.39 \times 10^{-1}$ & \\
\hline 7 & 8 & 1.2080068 & $6.52 \times 10^{-8}$ & $* * *$ \\
\hline 8 & 9 & 2.7840578 & $2.92 \times 10^{-29}$ & $* * *$ \\
\hline 9 & 10 & 4.9330813 & $2.16 \times 10^{-34}$ & $* * *$ \\
\hline
\end{tabular}

The same trend for the probability of bitter taste was demonstrated for the shaded leaves of the males (Fig. 2). Considering that the graphic representation demanded 24 figures to show the impact of the transpiration, leaf temperature and photosynthesis, the figure number was reduced by grouping the similar responses of the probability for the bitter taste. Therefore, the bitterness note response related to the temperature/transpiration occurring in all the types of the shading (understory and monoculture) are presented by Fig. 2A for the males, and by Fig. $3 \mathrm{~A}$ and $3 \mathrm{C}$ for both the sexes in relation of net photosynthesis.

The leaves from the female plants showed bitterer taste than the males considering the response based on the leaf temperature (transpiration) and net photosynthesis (Fig. 1-3). When shaded, the leaves from the male plants had high probability to be evaluated by the note 5 (normal-soft taste) and in a sequence by the notes 6, 7 and 4 (Fig. 2A and 3C), while from the females showed high probability to be evaluated by the note 7 (normal-bitter) followed by $6,8,5$ (Fig. 1A, 1B, 1C and 3B).

Evaluating the bitter taste of the leaves originated from the plant tips, the difference observed between the females (Fig.1D and 3B) and males (Fig. 2B and 3D) became more satisfied for the Brazilian taste. When young and non-shaded, the leaves from the males (Fig. 2B and 3D) were judged by notes the 5 (normal-soft taste) and 4 (soft-normal taste), followed by the notes 6, 7 (normal-bitter) and even 1 (highly soft taste). The leaves from female tips in yerba mate monoculture were evaluated with high probability by note 5 (normal-bitter) followed by notes 6, 7, 4 (Fig. 1D and 3B). 
A
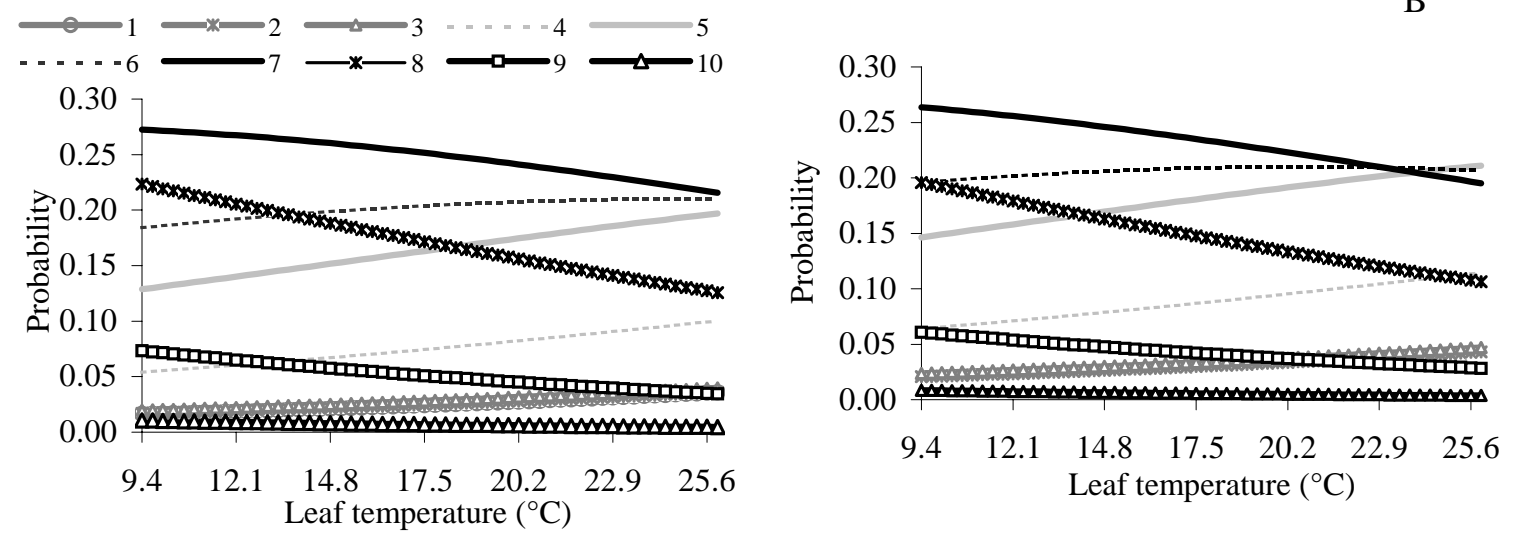

C
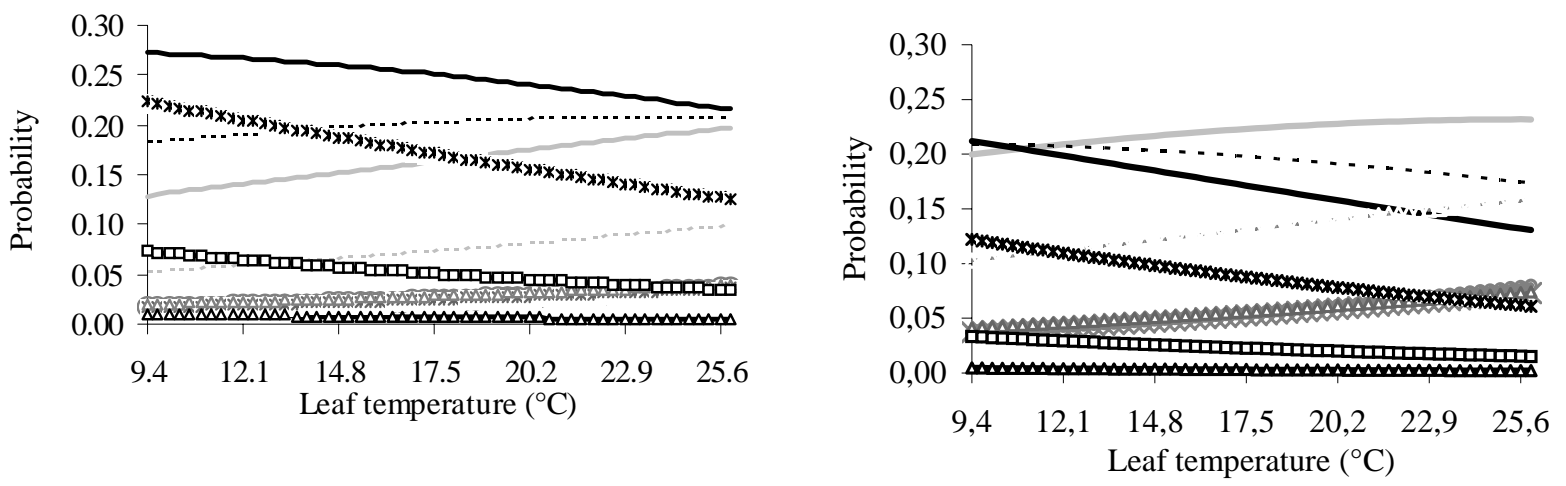

Figure 1 - Probability to occur a note (1-10) for a bitter taste of "chimarrão" dependent on leaf temperature $\left({ }^{\circ} \mathrm{C}\right) /$ transpiration $\left(E-\mathrm{mol} \mathrm{H}_{2} \mathrm{O} \mathrm{m}{ }^{-2} \cdot \mathrm{s}^{-1}\right)$. Leaves were collected on females from: $\mathbf{A}$ / inside of crown from plants grown in forest understory; $\mathbf{B} /$ tips of plants grown in forest understory; $\mathbf{C}$ / inside of crown of plants grown in monoculture; $\mathbf{D}$ / tips of plants grown in monoculture 

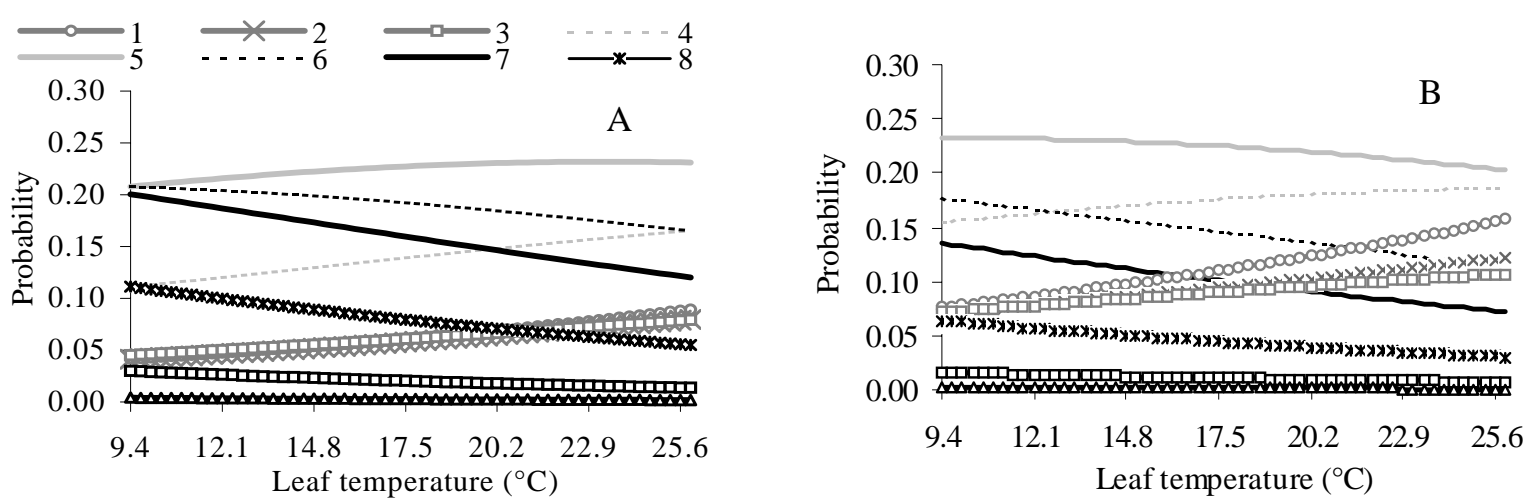

Figure 2 - Probability to occur a note (1-10) for a bitter taste of "chimarrão" dependent on leaf temperature $\left({ }^{\circ} \mathrm{C}\right) /$ transpiration $\left(E-\mathrm{mol} \mathrm{H}_{2} \mathrm{O} \mathrm{m}{ }^{-2} \cdot \mathrm{s}^{-1}\right)$. Leaves were collected on males from: $\mathbf{A} /$ shade - originated from plants grown in forest shade and inside of crown of plants grown in monoculture; $\mathbf{B}$ / tips of plants grown in monoculture

It was interesting to observe that the note for the bitter taste judged for the leaves from the tips of the females grown in the monoculture showed similar response for males in all types of the shading (compare Fig. 1D, 3B with 2A, 3C). Similar responses of the intensity of the bitter taste influenced by the leaf temperature $(T l)$ and transpiration $(E)$ were demonstrated. For this reason, the responses were grouped in only one graphical view (Fig. 1 and 2).

The increase of $T l / E$ explained the higher probability to occur the note up to 5 judged for yerba mate "chimarrão" provided by the male plants (Fig. 2), and up to 6 in the females (Fig. 1). Inversely, increasing the leaf temperature/ transpiration would induce the lower probability to occur the notes of highly bitter taste. It meant that the increase of the temperature from 9.4 to $25.6^{\circ} \mathrm{C}$ and transpiration from 0 to $0.0095 \mathrm{~mol} \mathrm{~m}^{-}$ ${ }^{2} \mathrm{~s}^{-1}$ of yerba mate leaves resulted in the softer taste and lower probability to occur the leaves with bitter taste.

The increase of the net photosynthetic rate from $0.3 \mu \mathrm{mol} \mathrm{CO}_{2} \mathrm{~m}^{-2} \mathrm{~s}^{-1}$ (negative values meant that the respiration rate was higher than the photosynthetic rate) to $15.1 \mu \mathrm{mol} \quad \mathrm{CO}_{2} \mathrm{~m}^{-2} \mathrm{~s}^{-1}$ explained the weak increasing slope for the notes from 7 to 9 considering the leaves collected from the females in the shade conditions. The leaves of the females from the tips (Fig. 3B) and the males from the shade (Fig. 3C) showed a weak increasing slope for the notes 7 and 8 (normal and bitter taste) when the photosynthesis augmented, whereas those from the male tips showed a weak increasing slope for the notes 6 and 7 (Fig. 3D).
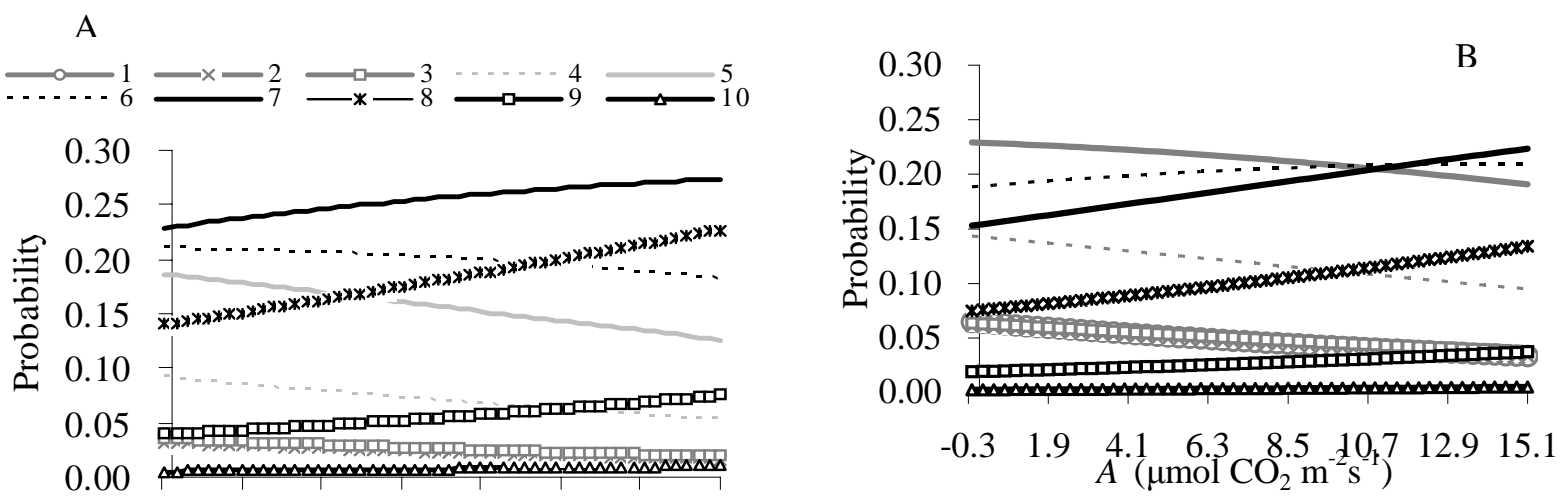

$\begin{array}{llllllll}-0.3 & 1.9 & 4.1 & 6.3 & 8.5 & 10.7 & 12.9 & 15.1\end{array}$ $A\left(\mu \mathrm{mol} \mathrm{CO}_{2} \mathrm{~m}^{2-1} \mathrm{~s}\right)$ 


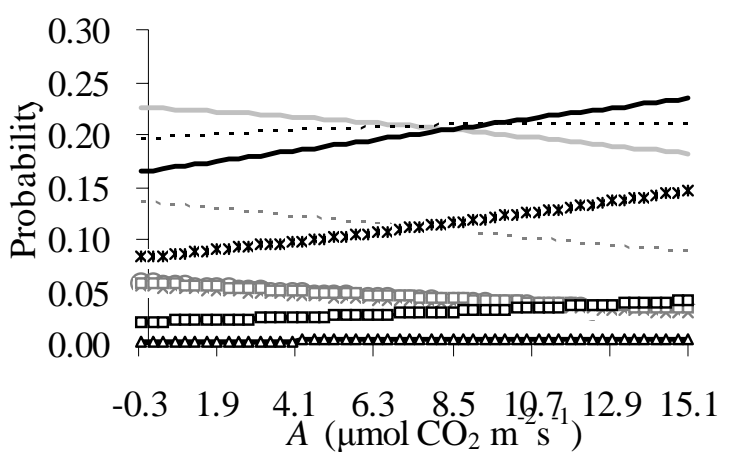

$\mathrm{C}$

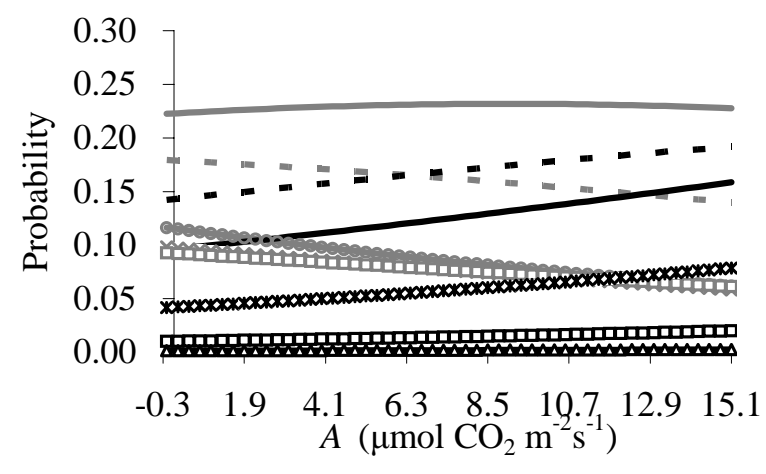

$\mathrm{D}$

Figure 3 - Probability to occur a note (1-10) for a bitter taste of "chimarrão" dependent on net photosynthesis $\left(A-\mu \mathrm{mol} \mathrm{CO}_{2} \mathrm{~m}^{-2} \mathrm{~s}^{-1}\right)$. Leaves were collected on: $\mathbf{A} /$ females and $\mathbf{C} /$ males from shade conditions - plants grown in forest shade and inside of crown of plants grown in monoculture; $\mathbf{B}$ / tips of females and $\mathbf{D}$ / males grown in monoculture

\section{DISCUSSION}

Multiple response of yerba mate taste related with the environmental and physiological factors showed that the light environment impact on the bitter taste did not confirm the paradigm of yerba mate industries. The leaves originated from any type of the shading provided the beverage of bitterer taste than from the non-shading (Tables 1 and 2). The inter- and intra-specific shading, as well as selfshading, did not differ in their impact on the quality (Fig. 1A, 1B, 1C). In previous work, the positive correlation between gas exchange and PPFD was established (Rakocevic et al., 2007a). Generally, the increasing values of the net photosynthetic rate explained the weak increasing slopes for the notes 6-9 and slightly decreasing slopes for the notes 1-5 (Fig. 3).

The leaves originated from the males were softer than the females in all the observed situations. The sensorial sexual dimorphism in yerba mate (Fig. 13 , Tables 1 and 2) was added to previous conclusions about the functional sexual dimorphism of this species. The functional strategy of yerba mate females, trying to finish the reproductive process, was to proportionate the relative increase of $A$ and $E$ on the self-shaded leaves, through the superior $g_{s}$ compared to the males (Rakocevic et al., 2007a). Previous analysis of yerba mate quality, from the experiment conduced exclusively in the monoculture, showed that the leaves originated from the tips of the males were less bitter than the females. The bitter taste was positively correlated with $\mathrm{Zn}$ and $\mathrm{Mg}$ contents in the females, and with $g_{s}$ and Mn content in males, while negatively correlated with K content (Rakocevic et al., 2007b). The analysis of the current trial confirmed the previous conclusions about the softer taste of the leaves originated on the tips of the trees, in this case, both the males and females (Fig. 1-3).

The sexual functional dimorphism manifested on the shaded leaves can partially explain the taste differences between the males and females in the shade, considering the higher photosynthetic rate of the females in the same light conditions trying to complete the cycles of reproduction (Rakocevic et al., 2007a). In this sense, greater functional effort of the females (net photosynthesis) justified greater notes for the bitter taste in the females grown in forest compared to the males (Fig. 3A and 3B). Meanwhile, the increase of the temperature from 9.4 to $25.6^{\circ} \mathrm{C}$ and the transpiration from 0 to $0.0095 \mathrm{~mol} \mathrm{~m}^{-2} \mathrm{~s}^{-1}$ on yerba mate leaves explained the softer taste and lower probability to occur the leaves with bitter taste (Fig. 1 and 2).

The leaf-age did not directly influence yerba mate taste, probably due to the leaves grouped in only two leaf-age populations corresponding to two distinct leaf positions on the tree crown. The photosynthetic and transpiration rates are positively related with the temperature (Fig. 1) corresponding to more abundant light conditions, where generally the younger leaves are localised. The leaves from the tips of yerba mate plants grown in the 
monoculture showed softer taste (Fig. 1 and 2), which was in accord with the knowledge about the processed green tea. The young leaves in Camellia sinensis (tea plant) rich in the metals have been of high quality compared to the old leaves (Tsushida \& Takeo, 1977).

During a diurnal-scale period, under high irradiance, the concentration of non-structural carbohydrates in well-waters leaves of the sunflower was found to two-fold from the sunrise to midday of active photosynthesis (Correia et al., 2006). On the other hand, the content of the soluble sugars in the leaves increased during the night and in sunrise. Also, the content of the soluble starch and sugar were increased in the diurnal period when one or more agents as drought (Correia et al., 2006) or infection (Muthuchelian et al., 2005) acted. In this sense, daytime and plant stage have to be respected in future yerba mate taste evaluation experiments.

From the study, following conclusions could be drawn:

- The inter and intra-specific competition for the light and self-shading showed the same effect on yerba mate beverage taste. All types of the shading (forest shading and self-shading inside the crown in the plants grown in the monoculture) resulted in bitterer taste of the processed yerba mate leaves compared to the leaves originated under the direct sun exposure. Generally, the leaves from plants grown in the monoculture showed less bitterness than those grown in the forest. This conclusion was completely opposite to conventionally accepted paradigm of yerba mate industries;

- The leaves from the tips (younger leaves) of the plants grown in the monoculture originated the beverage "chimarrão" of softer taste. This was similar to the secular knowledge experienced in Camellia sinensis (tea plants) exploration;

- Yerba mate males produced the leaves with less bitter taste in any light environment (forest or monoculture). When the plantation was directed to "chimarrão" production, the future management could be modified in direction of lowering the ratio between males and females. For this, masculinization of the plantations in the monoculture have to be offered, i.e. the tests of early hormone applications;

- The taste was related to the photosynthetic and transpiration rates and leaf temperature. In the shade conditions the taste modification was directly related to the bitterness, which could be explained by the leaf temperature decrease in the diurnal scale.

The limitation in generalizing the conclusions previously exposed was the evaluation experienced only in one collection date, at the end of May. This corresponded to the beginning of the winter growth pause (Bazzo \& Rakocevic, 2005) and to optimum time for harvesting. Considering that the collection of primary material for the industrial processing occurred during the whole-year period, the evaluations in other growth stages (pause and sprouting) and the months of the year could be recommended to better simulate the production systems. To improve the taste, the experiment considering the diurnal-scale collection of yerba mate leaves could be conduced in future. Also, a method of hedonic testers has been shown as extremely subjective (Rakocevic et al., 2007b) indicating that more objective methods in yerba mate sensorial testing should be used in future, as the standardizing recognition with the electronic tongue (Ivarsson et al., 2001).

\section{ACKNOWLEDGEMENTS}

A grant for M. Rakocevic, visiting researcher, provided by the $\mathrm{CNPq}$ Brazil is gratefully acknowledged. We thank to the technicians from the Embrapa Florestas and URI for their technical assistance, and to Yerba Mate "Barão" Industry for kindly offering the experimentation fields.

\section{RESUMO}

Mediu-se a intensidade de amargor da bebida preparada a partir de folhas da erva-mate (Ilex paraguariensis) de diversas idades, situadas em duas posições na copa (interior e ponteiras), produzidas por plantas masculinas e femininas cultivadas na floresta antropizada e em monocultura. As trocas gasosas foliares, a temperatura de folhas e a densidade de fluxo de fótons fotossinteticamente ativos também foram medidas. Com isso verificou-se que a idéia corrente de que o sombreamento está diretamente relacionado ao sabor suave do chimarrão é completamente equivocada, já que as competições inter- e intra-específicas por luz e autosombreamento provocaram o mesmo efeito no sabor do chimarrão, isto é, todos os tipos de 
sombreamento resultaram em sabor mais amargo de folhas processadas do de pleno sol. Assim, as folhas de plantas cultivadas em monocultura mostraram-se menos amargas do que aquelas de plantas manejadas sob a floresta. Além disso, as folhas de ponteiras (mais jovens) da monocultura originaram o chimarrão mais suave e os machos produziram folhas menos amargas que as fêmeas em ambos ambientes luminosos (floresta e monocultura). O sabor mostrou-se relacionado à fotossíntese, à transpiração e à temperatura de folha. Em sombreamento a modificação de sabor foi direcionada ao aumento de amargor e, aparentemente, relacionada ao decréscimo da temperatura de folhas e da transpiração na escala diurna.

\section{REFERENCES}

Amarine, M. A., Pangborn, M. R., Roessler, E. B., 1965. Principles of Sensory Evaluation of Food. Academic Press, New York.

Anesini, C., Ferraro, G., Filip, R. (2006), Peroxidase-like activity of Ilex paraguariensis. Food Chemistry, 97, 459-464

Ashby, D.; Pocock, S. J.; Shaper, A. G. (1986), Ordered polytomous regression: as example relating serum biochemistry and hematology to alcohol consumption. Apply Statistics, 35, 289-301.

Ashihara, H. (1993), Purine metabolism and the biosynthesis of caffeine in mate leaves. Photochemistry, 33(6), 1427-1430.

Bazzo, K. C. de, Rakocevic, M. (2005), Periodicidade no crescimento vegetativo de Ilex paraguariensis (St. Hil.) Aquifoliaceae. Série Documentos - Embrapa Florestas, 117, CD-ROM.

Correia, M. J., Osório, M. L., Osório, J., Barrote I., Martins M., David M. M. (2006), Influence of transient shade periods on the effects of drought on photosynthesis, carbohydrate accumulation and lipid peroxidation in sunflower leaves. Environmental and Experimental Botany, 58(1-3), 75-84.

Cox, Ch.; Chuang, Ch. (1984), A comparison of chisquare partioning and two logit analyses of ordinal pain data from a pharmaceutical study. Statistics in Medicine, 3, 273-285.

Dedecek, R. A., Philipovsky, J. F., Medrado, M. J. S. (2003), Efeito da intensidade de movimentação do solo na produção de soja nas entrelinhas da erva-mate. Boletim de Pesquisa Florestal, 47, 3-18.

Eibl, B., Fernandez, R. A., Kozarik, J. C., Lupi, A., Montagnini F., Nozzi, D. (2000), Agroforestry systems with Ilex paraguariensis (American holly or yerba mate) and native timber trees on small farms in Misiones, Argentina. Agroforestry Systems, 48, 1-8.
Esmelindro, M. C., Toniazzo, G., Lopes, D., Oliveira, D., Dariva, C. (2005), Effects of processing conditions on chemical distribution of mate tea leaves extract obtained from $\mathrm{CO}_{2}$ extraction at high pressures. Journal of Food Engineering, 70, 588-592.

Heraut-Bron, V., Robin, C., Varlet-Grancher, C., Afif, D., Guckert, A. (1999), Light quality (red: far-red ratio): does it affect photosynthetic activity, net $\mathrm{CO}_{2}$ assimilation, and morphology of young white clover leaves? Canadian Journal of Botany, 77, 1425-1431.

Hoppe, M., Knopp, E., Medrado, M. J. S. (1996), Ervamate: diagnóstico e perspectivas de desenvolvimento. In-Erva-mate: diagnóstico e perspectivas de desenvolvimento. Prefeitura Municipal, Venâncio Aires, pp. 7-22.

Ivarsson, P., Holmin, S., Höjer, N.E.. Krantz-Rülcker, C. Winquist, F. (2001), Discrimination of tea by means of a voltammetric electronic tongue and different applied waveforms. Sensors and Actuators, B Chemical, 76, 449-454.

Lamond, E., 1977. Laboratory Methods for Evaluation of Foods. Food Research Institute, Canadian Department of Agriculture, Ottawa.

Lemaire, G. (1995) Ecophysiological approaches to intercropping. In-Ecophysiology of tropical intercropping, eds. H. Sinoquet, P. Cruz. INRA Editions, Paris, pp. 9-28.

Lunceford, N., Gugliucci, A. (2005), Ilex paraguariensis extracts infibit AGE formation more efficiently than green tea. Fitoterapia, 76, 419-427.

McCullagh, P. (1980), Regression models for ordered data (with discussion). Journal of the Royal Statistical Society, B, 42, 109-142.

Mosele S. H. (2002), A governança na cadeia agroindustrial da erva-mate na região Alto Uruguai Rio Grandense sob a ótica da cadeia de suprimentos. MS Thesis. UFRGS, Porto Alegre, Brazil.

Muthuchelian, K., La Porta, N., Bertamini, M., Nedunchezhian, N. (2005), Cypress canker induced inhibition of photosynthesis in field grown cypress (Cypressus semprevirens L) needles. Physiological and Molecular Plant Pathology, 67, 33-39.

Paul, M. J., Foyer, C. H. (2001), Sink regulation of photosynthesis. Journal of Experimental Botany, 52, 1383-1400.

Petersen, P., Tardin, J.M., Marochi, F. (2000) From mate extractivism to the regenerative management of Araucaria forest. Heia Newsletter, September 2000 , 17-18.

Piccolo, G. A., Galantini, J.A., Rosell, R.A. (2004), Organic carbon fractions in yerba mate plantation on a subtropical Kandihumult of Argentina. Geoderma, 123, 333-341.

Rakocevic, M., Sturion, J. A., Medrado, J. S. M., Lavoranti, O. J., Mosele, S. H., Valduga, A. T. (2005), Ecophysiological and productive properties as tool for breeding of mate (Ilex paraguariensis St. Hil.). Boletim da Pesquisa Florestal, 51 (in press). 
Rakocevic, M., Medrado, M. J. S., Lavoranti, O. J. (2007a), Leaf gas exchange differences between males and females of mate. Brazilian Archive of Forest Research, $\mathbf{5 5}$.

Rakocevic, M., Medrado, M. J. S., Lavoranti, O. J, Valduga, A. T. (2007b), Quality of mate leaves originated from males and females. Brazilian Archive of Forest Research, $\mathbf{5 5}$.

Saldanã, M. D. A, Mohamed, R. S., Mozzafera, P. (2000), Supercritical carbon dioxide extraction of methylxanthines from maté tea leaves. Brazilian Journal of Chemical Engineering, 17(3), 251-259.
Scherer, R.A. (1997), Early selection of yerba mate (Ilex paraguariensis St.Hil.). $\mathrm{PhD}$ Thesis. Rheinischen Freidrich-Wilhelms-Universitat, Bonn.

Tsushida, T., Takeo, T. (1977), Zinc, Cooper, Lead and Cadmium contents in green tea. Journal of the Science of Food and Agriculture, 28, 255-258.

Valduga, A.T., Battestin, V., Finzer, J.R.D. (2003), Secagem de extratos de erva-mate em secador por atomização. Ciência de Tecnologia de Alimentos, 23(2), 184-18. 
PÁGINA EM

BRANCO 